\title{
PENGARUH PDRB PERKAPITA DAN INDEKS PEBANGUNAN MANUSIA (IPM) TERHADAP PEMERATAAN PENDAPATAN DI PROVINSI JAWA TIMUR$$
\text { TAHUN } 2013 \text { - } 2017
$$$$
\text { Nur Afini }
$$ \\ FEBI UINSA Surabaya | nur.afini38@gmail.com
}

\begin{abstract}
Abstrak: Penelitian ini bertujuan menjawab pertanyaan tentang adakah hubungan variabel PDRB Perkapita dan Indeks Pembangunan Manusia (IPM) terhadap pemerataan pendapatan di provinsi Jawa Timur Tahun 2013 - 2017. Metodologi yang digunakan adalah menggunakan regresi data panel dengan medel random effects. Hasil dari penelitian nilai $F$ hitung sebesar 6,426432 dengan probabilitas variabel PDRB Perkapita sebesar 0,001999 sehingga lebih kecil dari pada nilai signifikasi sebesar 0,05 (5\%) sehingga Ho ditolak dan $\mathrm{HI}$ diterima. Dari hasil pengujian dapat disimpulkan bahwa secara simultan semua variabel independen diantaranya PDRB Perkapita (XI), Indeks Pembangunan Manusia (X2) berpengaruh signifikan secara bersama - sama terhadap variabel dependen yaitu Pemerataan Pendapatan (Y). Nilai t hitung dari PDRB Perkapita sebesar 3,152327 sedangkan probabilitas variabel PDRB Perkapita sebesar 0,001999. Dibandingkan dengan nilai signifikansi sebesar 0,05 (5\%) menunjukkan bahwa nilai probabilitas variabel PDRB Perkapita lebih rendah dibandingkan nilai signifikansi, yang artinya Ho ditolak dan $\mathrm{HI}$ diterima sehingga PDRB Perkapita memiliki pengaruh secara signifikan terhadap pemerataan pendapatan di provinsi Jawa Timur. nilai $t$ hitung dari variabel Indeks Pembangunan Manusia sebesar I,678284 sedangkan probabilitas variabel Indeks Pembangunan Manusia sebesar 0,095000. Indeks Pembangunan Manusia tidak memiliki pengaruh secara signifikan namun berhubungan positif terhadap pemerataan pendapatan di provinsi Jawa Timur.
\end{abstract}

Keywords : PDRB Perkapita, Indeks Pembangunan Manusia (IPM), Rasio 


\section{Pendahuluan}

Pembangunan ekonomi khususnya pada negara berkembang tergantung pada keberhasilan indikator sosial yang ada di negara tersebut. Pembangunan ekonomi akan berhasil apabila didukung dengan menurunnya tingkat ketimpangan pendapatan disuatu negara. Jika distribusi pengeluaran sosial (social spending) tidak merata hal ini akan menjadi penyebab terjadinya ketimpangan disuatu negara atau wilayah, karena pembangunan ekonominya sebagaian besar hanya dirasakan oleh kalangan mengah keatas atau orang kaya. Pemerataan distribusi pendapatan sering menjadi perhatian penting pemerintah untuk mengambil suatu kebijakan pembangunan demi keberhasilan perekonomian negara. Dari hasil beberapa penelitian menyatakan, jika pemerintah mengambil kebijakan yang fokus utamanya adalah pertumbuhan ekonomi saja maka akan meningkatkan kesenjangan pendapatan. Salah satu alat untuk mengukur tingkat kesejahteraan masyrakat disuatu wilayah adalah dengan menggunakan PDRB per kapita.

Pada proses terjadinya kesenjangan pendapatan di suatu wilayah salah satu penyebab adalah adanya perbedaan kondisi demografi yang cukup signifikan antar masing-masing daerah. Perbedaan laju pertumbuhan, penduduk, struktur ekonomi, kualitas pendidikan, dan kesehatan, karakteristik masyarakat. Keadaan demografi dan infrastruktur yang baik akan secara alami akan meningkatkan produktivitas kerja, karena mudahnya distribusi barang dan jasa sehingga meningkatkan pertumbuhan ekonomi daerah. ${ }^{1}$ Selain itu, hal yang paling penting untuk meningkatkan produktivitas kerja adalah kualaitas sumber daya manusia. Untuk melihat gambaran kondisi kualitas sumber daya manusia dapat dilihat dari Indeks Pembangunan Manusia (IPM) yang mempunyai beberapa indikator diantaranya kesehatan, dan pendidikan. 
Dalam proses pertumbuhan ekonomi perlu adanya pemerataan agar terciptanya kesejahteraan masyarakat. Pertumbuhan ekonomi yang terlalu cepat tidak mencerminkan keberhasilan pembangunan, karena akan menimbulkan ketimpangan distribusi pendapatan. Terdapat kondisi trade off antara tingginya pertumbuhan ekonomi dengan pemerataan pendapatan dalam proses pemabangunan ekonomi. Dibutuhkan waktu yang panjang untuk meningkatkan pertumbuhan ekonomi ketika pembangunan ekonomi difokuskan pada pemerataan pendapatan saja. Sebaliknya, akan terjadi ketimpangan distribusi pendapatan disuatu wilayah jika pembangunan ekonomi difokuskan pada tingkat pertumbuhan ekonomi yang tinggi. ${ }^{2}$

Pemerataan pendapatan antar wilayah adalah permasalahan dalam pembangunan yang dilakukan secara spasial (tata ruang). Pencapaian pertumbuhan ekonomi tidak dapat mengatasi masalah kesenjangan pendapatan karena belum meratanya distribusi pendapatan. Tidak meratanya proses pembangunan disesbabkan karena adanya wilayahwilayah yang mengalami pertumbuhan yang cepat, dan beberapa wilayah lainnya mengalami pertumbuhan ekonomi yang lambat. Masing-masing daerah memiliki karakteristik yang berbeda, oleh karena itu tidak seluruh wilayah mengalami kemajuan dan perkembangan. Wilayah yang tidak mengalami kemajuan dan perkembangan yang sama, disebabkan oleh perbedaan hasil sumber daya yang dimiliki, tingkat mobilitas faktor produksi antar wilayah, sumber daya manusia diukur dengan Indeks Pembangunan Manusia (IPM) yang berbeda antar wilayah. Hal tersebut merupakan beberapa faktor yang menyebabkan kesenjangan dan tidak meratanya distribusi pendapatan antar wilayah. Bedasarkan latar belakang masalah yang telah dijelaskan diatas, maka peneliti tertarik untuk mengusung topik dalam penelitian ini dengan judul "Pengaruh PDRB Perkapita dan IPM terhadap Pemerataan Pendapatan di Provinsi Jawa Timur Tahun 2013-2017.

${ }^{2}$ Mudrajat Kuncoro, Ekonomi Pembangunan. (Jakarta: Penerbit Salemba Empat, 2006), hal II4 


\section{Landasan Teori}

\section{Pembangunan Ekonomi}

Pembangunan ekonomi disuatu negara menentukan keberhasilan yang berkelanjutan supaya sumber daya dapat dinikmati dalam jangka panjang dan tidak mengalami kemusnahan. Di dalam suatu negara ada dua konsep yang tidak dapat dipisahkan, dua konsep tersebut adalah pertumbuhan dan pembangunan ekonomi. Pembangunan ekonomi dapat didefinisikan sebagai suatu perubahan struktur ekonomi, perubahan sosial, mengurangi tingkat kemiskinan dan pengangguran serta semakin meratanya kesejahteraan masyarakat dalam konteks pertumbuhan yang bersifat multimensional. ${ }^{3}$

\section{Pertumbuhan Ekonomi}

Pada keadaan perekonomian disuatu wilayah akan dikatakan mengalami pertumbuhan apabila kegiatan ekonominya meningkat atau lebih tinggi dari pada tingkat kegiatan ekonomi ditahun sebelumnya. Proses pembangunan baru akan terjadi apabila jumlah barang dan jasa secara fisik pada kegiatan ekonomi tersebut semakin bertambah pada tahun-tahunnya. Keberhasilan pembangunan disuatu wilayah memiliki indikator pertumbuhan ekonomi. Pertumbuhan ekonomi sendiri dapat diartikan sebagai pertumbuhan pendapatan masyarakat atau penduduk secara keseluruhan sebagai gambaran kenaikan seluruh nilai tambah atau value addid yang telah dihasilkan pada kegiatan ekonomi disuatu wilayah.

Perroux mempopulerkan teori kutub dimana pertumbuhan tidak berkembang pada seluruh wilayah pada waktu yang bersamaan. Pertumbuhan ekonomi hanya terjadi pada daerah-daerah tertentu yang merupakan pusat (kutub) pertumbuhan dengan karakteristik yang berbeda-beda disetiap wilayah $1 .^{4}$

\footnotetext{
${ }^{3}$ Lincolin Arsyad, Ekonomi pembangunan Edisi Keempat. (Yogyakarta: Badan Penerbit Sekolah Tinggi Ilmu Ekonomi YKPN, 1999), Hal 147-148.

${ }^{4}$ Lincolin Arsyad, Ekonomi pembangunan Edisi Keempat. (Yogyakarta: Badan Penerbit Sekolah Tinggi Ilmu Ekonomi YKPN, 1999), Hal 147-148.
} 


\section{Produk Domestik Regional Bruto (PDRB)}

Konsep Produk Domestik Regional Bruto (PDRB)

Meningkatkan kesejahteraan masyarakat dan mengurangi tingkat pengangguran serta kesenjangan pendapatan masyarakat dibutuhkan berbagai usaha diantaranya dengan pembangunan ekonomi yang merata. Dalam meningkatkan perekonomian disuatu wilayah perlu adanya kinerja yang baik dalam mengelola sumber daya alam maupun sumber daya manusia yang dimiliki. Untuk mengukur kegiatan ekonomi disuatu wilayah PDRB dapat menjadi salah satu indikator perhitungan, PDRB sendiri dapat diartikan sebagai hasil kinerja perekonomian suatu wilayah pada kurun waktu atau periode tertentu dapat digambarkan dengan menggunakan indikator makro ekonomi yang disebut Produk Domestik Regional Bruto (PDRB). ${ }^{5}$

\section{Produk Domestik Regional Bruto (PDRB) Perkapita}

Sedangkan PDRB Perkapita didapatkan dari pembagian PDRB atas harga berlaku dengan jumlah penduduk pada pertengahan tahun. Dari PDRB Perkapita kita dapat mengetahui besarnya pendapatan yang diperoleh oleh masyarakat pada suatu wilayah, data PDRB perkapita dihitung mulai dari jumlah bayi yang baru lahir hingga dengan orang yang sudah tua. PDRB Perkapita juga menjadi salah satu indikator untuk mengetahui bagaimana kondisi disuatu wilayah dalam pariode tertentu, dapat di lihat dengan Pendpatan Domestik Regional Bruto (PDRB) atas harga konsta atau atas harga berlaku. Jika pendapatan perkapita mengalami peningkatan, otomatis akan mendorong naiknya tingkat daya beli atau konsumsi masyarakat. Ketika daya beli atau konsumsi masyarakat meningkat otomatis juga akan mendorong meningkatnya produksi barang dan jasa.$^{6}$

\section{Indeks Pembangunan Manusia (IPM)}

Pengertian Indeks Pembangunan Manusia (IPM)

Indeks Pembangunan Manusia (IPM) dapat diartikan sebagai suatu alat ukur yang digunakan untuk membandingkan harapan hidup, melek huruf, pendidikan serta standart hidup diseluruh negara di dunia.

\footnotetext{
${ }^{5}$ Lincolin Arsyad, Ekonomi pembangunan Edisi Keempat. (Yogyakarta: Badan Penerbit Sekolah Tinggi Ilmu Ekonomi YKPN, 1999), Hal I47-I48.

6 Denny Iswanto, Ketimpangan Pendapatan antar Kabupaten/Kota dan Pertumbuhan Ekonomi di Provinsi Jawa Timur, No I, Vol 4. (April, 20I5), hal 42
} 
Karena situasi baru pada tahun 2000 tentang depletion sumber daya alam, eksploitasi lingkungan, berubahnya iklim, perlindungan sosial, ketahanan energi dan pangan, dan pembangunan yang berpihak pada masyarakat miskin. Dimulai dari tahun 2015 seluruh pembangunan mengacu pada konsepan baru yakni Tujuan Pembangunan Berkelanjutan (TPB) atau lebih sering disebut dengan Sustaineble Development Goals (SGDs). Dalam konsepan ini terdapat tujuan mengenai dengan pembangunan manusia yang menjadi hal penting pada perencanaan dan strategi bembangunan berkelanjutan. ${ }^{7}$

\section{Metode Penelitian}

Pada penelitian ini menggunakan teknik analisis data dan pengelolahan data diantaranya analisis regresi data panel, dimana pada teknik ini menggabungkan data cross section dan time series yang bertujuan untuk mendapatkan gambaran secara menyeluruh hubungan antara variabel independen mempengaruhi pemerataan pendapatan baik secara parsial maupun secara simultan. Dalam penelitian ini dapat digambarkan menggunakan persamaan model sebagai berikut :

Y_RatioGini $=\beta \mathrm{O}+\beta_{-} 1$ PDRB 【kpt】_it+ $\beta \_(2)$ 『IPM】_it+ $\epsilon_{-}$(it )

Keterangan

Y_RatioGini

PDRBpkt

IPM

$\epsilon$
$=$ Ratio Gini

= Produk Domestik Bruto Perkapita

= Indeks Pembangunan Manusia

$=$ eror

Pembahasan

A. Pengaruh Secara Simultan PDRB Perkapita, dan Indeks Pembangunan Manusia (IPM) Terhadap Pemerataan Pendapatan di Provinsi Jawa Timur

\footnotetext{
$\overline{{ }^{7} \text { BPS Indeks Pembangunan Manusia Nasional }} 2017$
} 
Dari hasil pengujian, penelitian ini menunjukkan bahwa PDRB Perkapita (X1), Indeks Pembangunan Manusia (X2) berpengaruh secara simultan atau secara bersama-sama terhadap variabel Pemerataan Pendapatan ( $(Y)$. Dapat dibuktikan dengan hasil pengujian nilai $F$ hitung sebesar 6,426432 dengan probabilitas variabel PDRB Perkapita sebesar 0,001999 sehingga lebih kecil dari pada nilai signifikasi sebesar 0,05 (5\%) sehingga Ho ditolak dan H1 diterima. Dari hasil pengujian dapat disimpulkan bahwa secara simultan semua variabel independen diantaranya PDRB Perkapita (X1), Indeks Pembangunan Manusia (X2) berpengaruh signifikan secara bersama-sama terhadap variabel dependen yaitu Pemerataan Pendapatan (Y).

Pada teori kutub yang dipopulerkan Perroux menjelaskan bahwa pemerataan tidak dapat terjadi disuatu wilayah karena pertumbuhan tidak akan berkembang pada seluruh wilayah dalam waktu yang bersamaan. Pertumbuhan ekonomi akan terjadi pada daerah-daerah tertentu yang merupakan pusat atau kutub pertumbuhan dengan karakteristik yang berbeda-beda pada setiap daerah. Dalam teori ini terdapat beberapa faktor yang dapat mempengaruhi pertumbuhan diantaranya sumber daya alam, sumber daya manusia, teknologi dan ilmu pengetahuan, dan sumber daya modal . 8

Pada hakikatnya pemerataan pendapatan adalah suatu keadaan dimana seluruh masyarakat yang tinggal disuatu wilayah dapat merasakan kesejahteraan untuk hidupnya. Menurut Simon Fuglsang distribusi pendapatan dipengaruhi oleh banyak faktor diantaranya faktor ekonomi maupun non ekonomi. Faktor ekonomi diantaranya keadaan makroekonomi wilayah, sedangkan faktor non ekonomi seperti kondisi demografi, keadaan alam, politik maupun budaya dari wilayah tersebut. ${ }^{9}$

${ }^{8}$ Arsyad, Ekonomi pembangunan Edisi Keempat. (Yogyakarta: Badan Penerbit Sekolah

Tinggi Ilmu Ekonomi YKPN, 1999), Hal I47-I 48

'Simon Fulgsang, "Determinants of Income Inequality : Sub-Saharan Perspective" Thesis. Aarhus University, 2013. 
ini membuktikan bahwa data dalam penelitian ini berdistribusi normal karena nilai $0.805>0.05$.

a) Uji Heteroskedastisitas

Berdasarkan hasil uji menujukkan nilai signifikansi masing-masing varibel $>0.05$, maka sesuai metode uji Glejser yang digunakan dalam penelitian hasilnya dapat dikatakan variabel independen yaitu variabel penerapan teknologi informasi bernilai 0,378 dan variabel kemampuan pengguna bernilai 0,418 jadi dikatakan bebas dari gejala heteroskedasitas.

b) Uji Multikolinieritas

Pada penelitian ini menggunakan alat statistik Variances Inflation Factor (VIF). Jika nilai tolerance lebih besar dari 0,1 dan nilai VIF lebih kecil dari 10 serta nilai matriks korelasi tidak ada yang lebih besar dari 0,5, maka tidak terjadi multikolinieritas. Berdasarkan tabel diatas menunjukkan nilai tolerance masing-masing variabel $>0.10$ yaitu $(0,909)$ dan nilai VIF masing-masing variabel < 10.00 yaitu (1100), maka dapat dikatakan tidak terjadi multikolonieritas dalam data penelitian tersebut.

c) Uji Autokorelasi

Dalam penelitian ini uji autokorelasi dilakukan dengan metode Uji Run dengan melihat nilai Asymp Sig (2-tailed) harus lebih besar 0,05. Berdasarkan hasil uji autokorelasi menunjukkan Asymp Sig.(2tailed) bernilai 0,118 yang artinya nilainya lebih besar dari 0,05 sehingga dapat disimpulkan model bebas dari gejala autokorelasi.

2. Uji Hipotesis

1) Untuk hipotesis pertama digunakan alat uji dengan metode regresi linier sederhana untuk menentukan 
ketetapan prediksi dari pengaruh yang terjadi antara variabel independen terhadap variabel dependen.

Data hasil uji menunjukkan bahwa nilai R sebesar 0,270 yang artinya hubungan antara penerapan teknologi informasi terhadap kinerja karyawan sebesar $27 \%$. Sedangkan untuk adjusted $R$ square menunjukkan nilai sebesar 0.057 yang artinya hanya 5,7\% variabel penerapan teknologi informasi mampu menjelaskan variabel kinerja karyawan sisanya sebesar $(100 \%$ - 5,7\%) $=94,3 \%$ dijelaskan olehvariabel lainnya yang tidak dimasukkan dalam pengujian ini.

Selain itu dari uji terlhat nilai $\mathrm{F}$ menunjukkan angka 4,578 dengan signifikansi sebesar 0,037 sehingga dapat disimpulkan bahwa penerapan teknologi informasi berpengaruh terhadap kinerja karyawan karena nilai signifikansi $<$ (kurang dari) 0,05.

$$
Y=15,176+0,292 X_{1}+e
$$

Dari persamaan tersebut menunjukkan nilai koefisien penerapan teknologi informasi yaitu sebesar 0,292 yang bernilai positif artinya bahwa variabel penerapan teknologi informasi mempunyai pengaruh positif dan signifikan terhadap kinerja karyawan, dengan nilai konstanta diketahui dalam tabel sebesar 15,176 yang diartikan sebagai nilai kinerja karyawan secara konstan.

2) $\mathrm{H} 2 \quad$ : Kemampuan pengguna mempunyai pengaruh terhadap hubungan antara penerapan teknologi informasi dengan kinerja karyawan

Uji interaksi dilakukan dengan menggunakan Moderated regression analysis (MRA) yaitu aplikasi dari regresi linier berganda dimana dalam persamaanya mengandung unsur interaksi (perkalian dua/lebih variabel independen). MRA dilakukan melalui uji signifikansi simultan (Uji F) dan Uji signifikansi parameter individual 
(Uji t) dengan ketentuan sebagai berikut: Uji signifikansi simultan (uji ststistik F). Jika anova atau F test menghasilkan nilai $\mathrm{F}$ hitung dengan tingkat signifikansi yang lebih kecil dari tingkat signifikansi yang ditentukan, maka model regresi dapat digunakan untuk memprediksi variabel Y. uji signifikansi parameter individual (Uji $\mathrm{t}$ statistik), jika variabel independen, moderating dan interaksi memberikan nilai koefisien parameter dengan tingkat signifikansi lebih kecil dari tingkat signifikansi yang ditentukan, maka dapat disimpulkan bahwa variabel tersebut adalah variabel moderasi. ${ }^{10}$

Berdasarkan hasil uji dapat diketahui nilai $R$ sebesar 0,298 yang artinya hubungan antara penerapan teknologi informasi terhadap kinerja karyawan yang dimoderasi oleh kemampuan pengguna sebesar 29,8\%. Sedangkan nilai Adjusted $R$ Square menunjukkan angka sebesar 0,040 yang berarti variabel kinerja karyawan dapat dijelaskan oleh variabel penerapan teknologi informasi yang dimoderasi oleh variabel kemampuan pengguna hanya sebesar $4 \%$ sisanya sebesar $(100 \%$ - $4 \%)$ $=96 \%$ dijelaskan oleh variabel-variabel lain yang tidak di uji dalam model penelitian ini.

Dari hasil uji menunjukkan nilai Fhitung sebesar 1,816 dengan nilai signifikansi sebesar 0,155 yang artinya nilai signifikansi lebih besar dari 0,05, maka dapat dikatakan bahwa secara bersama-sama variabel-variabel independen (penerapan teknologi informasi dan kemampuan pengguna) beserta variabel moderasi tidak berpengaruh secara signifikan terhadap variabel dependen yaitu kinerja karyawan.

$$
\mathrm{Y}=30,533-0,579-0,683+0,039 \mathrm{X} 1 \mathrm{X} 2+\mathrm{e}
$$

\footnotetext{
${ }^{10}$ Imam Ghozali, Aplikasi Analisis Multivarite DenganProgram SPSS(Yogyakarta:Universitas Diponegoro, 2006), 60
} 
Dari persamaan tersebut dapat ditunjukkan bahwa konstanta bernilai 30,533, sedangkan nilai koefisien masing-masing variabel berbeda-beda variabel penerapan teknologi informasi bernilai negative sebesar $(-0,579)$, kemampuan pengguna bernilai negatife sebesar $(-0,683)$, dan untuk variabel moderasi (interaksi antara penerapan teknologi informasi dan kemampuan pengguna) menunjukkan nilai positif sebesar 0,039. Selain itu nilai signifikansi tabel menunjukkan angka lebih besar dari 0,05 sehingga menjadi disimpulkan bahwa semua variabel bernilai tidak signifikan. Dengan kata lain variabel moderasi pada hasil uji penelitian ini disebut sebagai variabel moderasi potensial (homologiser) dimana nilai b2 dan b3 bernilai negative yaitu variabel yang potensial menjadi variabel moderasi yang mempengaruhi kekuatan hubungan antara variabel independen dan variabel dependen, variabel ini tidak berinteraksi dengan variabel independen dan tidak mempunyai hubungan yang signifikan terhadap variabel dependen.

\section{Penutup}

Hasil penelitian ini hipotesis pertama diterima, yaitu penerapan teknologi informasi mempunyai pengaruh positif yang signifikan terhadap kinerja karyawan, dengan kata lain variabel X1 berpengaruh terhadap variabel Y.

Penelitian ini menghasilkan hipotesis kedua diterima tetapi hasilnya menunjukkan koefisien variabel moderasi bernilai positif yang artinya variabel moderasi berpengaruh tidak signifikan dan bersifat memperlemah hubungan interaksi antara penerapan teknologi informasi dan kinerja karyawan. Sehingga disimpulkan bahwa kemampuan pengguna sebagai variabel moderasi potensial. Selain itu penelitian ini menunjukkan dari hasil uji regresi kedua secara bersama-sama (simultan) variabel-variabel independen beserta variabel moderasi tidak berpengaruh terhadap kinerja karyawan, jadi 
variabel kemampuan pengguna yang menjadi variabel moderasi tetapi tidak signifikan juga tidak dapat menjadi variabel dependen karena hasil uji menunjukkan nilai yang tidak signifikan. 


\section{DAFTAR PUSTAKA}

Arsyad, Lincolin. Ekonomi pembangunan Edisi Keempat. Yogyakarta: Badan Penerbit Sekolah Tinggi Ilmu Ekonomi YKPN, 1999

Iswanto, Denny. Ketimpangan Pendapatan antar Kabupaten/Kota dan Pertumbuhan Ekonomi di Provinsi Jawa Timur, No 1, Vol. 4, April, 2015.

Imam, Ghazali. Aplikasi Analisisi Multivariate dengan Program IBM SPSS 19 (edisi kelima). Semarang: Universitas Diponegoro, 2011.

Kuncoro, Mudrajat. Ekonomi Pembangunan. Jakarta: Penerbit Salemba Empat, 2006.

Kuncoro, Mudrajad. Ekonomi Pembangunan, Teori, Masalah, dan kebijakan, Yogyakarta: AMP YKNP, 1997.

Sjahfrizal, Ekonomi Wilayah dan Perkotaan. Padang: Rajawali Pers, 2012.

Sugiono, metodologi Penelitian Kuantitatif, Kualitatif dan R\&D, Bandung: ALFABETA, 2013.

Sukirno, Sadono. Pengantar Teori Makro Ekonomi. Jakarta: Selemba Empat, 1998.

Suryana, Ekonomika Pembangunan. Jakarta: Selemba Empat, 2000.

Todaro, Michael. dan Smith, Stephen. Pembangunan Ekonomi Edisi Kesebelas. Jakarta: Penerbit Erlangga, 2011. 